\title{
建筑设计在城市规划设计中的重要性
}

李伟

DOI:10.32629/btr.v3i4.3009

[摘要] 随着我国综合国力的不断提高,我国提出的城镇一体化以及社会主义现代化的不断推进,使得我国城市建设逐渐进入人们的视野。由 于建筑设计在城市规划中重要性的逐渐深入人心, 人们也越来越重视建筑设计在促进城市发展中举足轻重的重要作用。所以,要想规划好城市发 展布局,促进城市的整体发展,就必须明确掌握建筑设计与城市规划的含义, 了解进行建筑设计的必要性和重要性。

[关键词] 建筑设计; 城市规划; 重要性

\section{1 建筑设计对城市规划设计影响的综合性分析}

1. 1 建筑设计是城市规划设计得以实施的基础

在对城市规划设计的过程中, 需要合理的控制设计城市整体空间布局 的实际情况, 同时还需要对城市设计每一个元素之间的协调性和一致性进 行充分的考虑, 因此自然界和建筑物设计的协调性是非常重要的。在对建 筑设计的过程中, 对建筑的附属空间设计提出了严格的要求, 建筑物附属 空间需要将经济性、适用性、安全性和美观性之间进行协调设计, 然后在 对城市整体的微观层面进行设计。建筑设计在城市规划设计中的重要性是 显而易见的, 同时是城市规划设计整体的戏份项目, 还是城市规划设计的 基本内容, 在对城市进行规划设计的过程中, 其主要的设计内容是城市的 大格局布局。在城市规划设计的过程中需要合理控制的各种各样形状的建 筑物布局, 从而能够提高设计城市规划的观赏美感。

1.2 建筑设计是顺应城市规划的现实需要

在对城市进行规划设计的过程中, 城市整体的格局以及持续发展是 城市建设的最终目标。在设计中, 不仅需要融入城市的文化特色, 还需要 城市规划能够满足人们的需求。在城市规划设计的过程中, 建筑物设计 在城市规划设计中发挥着重要作用, 还是城市规划设计内容中的重要组 成部分, 而在设计建筑物的过程中, 不仅需要在设计中融入城市整体的 风格, 还需要在设计中融入建筑的文化特色。在完成城市规划设计的时 候, 需要严格的按照规划设计的标准要求进行设计。在对建筑进行设计 的过程中, 需要与周围环境进行有效的融合, 从而能够为人们打造一个 良好的居住环境。

\section{2 建筑设计与城市规划设计的内在联系}

2.1建筑设计对城市规划设计的影响

在对城市进行规划设计的过程中, 设计人员需要认识建筑设计在城市 规划设计中的重要性, 符合时代发展的要求和满足人们的需求。在实际中 设计建筑的时候, 不仅是对单个的建筑物进行设计, 还需要对建筑物周围 的环境以及所处的场地进行合理的设计。大部分设计人员在构建建筑物设 计图纸的过程中, 设计中缺乏当地的文化特色以及所处背景信息, 没有将 城市的文化特色以及环境情况与单个建筑物的设计进行有效的融合, 只是 重视建筑物设计形态的唯一性, 反而会造成城市规划设计的不合理, 不能 够与周围华景以及文化特点进行融合, 会对城市规划设计的协调性造成直 接的影响。在设计建筑物的时候, 需要充分的融入城市文化特点和发展方 向, 并且需要对传统的设计理念进行创新和优化, 从而能够保证城市规划 设计的协调性和合理性。

2. 2 建筑设计是城市规划设计的基础

(1) 建筑设计需展示城市的风土人情

在对建筑进行设计的过程中, 需要对中华民族区域的特色和文化特色
进行充分的考虑, 还需要对人们生活居住的功能进行考分的考虑, 保证建 筑设计能够符合时代的要求。在对建筑进行设计的过程中, 充分的融合当 地的人文风情和城市发展的需求, 保证建筑设计能够满足城市规划设计的 需求。在新时代不断发展的背景下, 建筑设计人员需要充分利用先进的设 计理念, 运用现代的设计手段进行建筑的设计, 保证建筑设计的完整性, 从 而能够进一步提高人们居住的环境质量。

(2) 建筑设计要能够展示出城市的各种功能

在城市建设的过程中, 需要对人们居住的生活质量进行提高。不论是 在建筑设计的过程中, 还是在城市规划设计的过程中, 都需要满足人们对 建筑设计的需求, 在设计中需要增加建筑空间的使用功能, 保证建筑设计 能够符合时代发展的要求。在对城市建筑规划功能进行设计的过程中, 其 中不同的建筑设计区域需要设置相对应的功能, 并且还需要对功能区域划 分进行明确工作, 在设计功能标准要求的过程中, 需要根据实现功能的实 际情况进行设计。

2. 3建筑设计要能够展示出城市的内涵景观

在对城市规划设计的过程中, 建筑物设计有着重要的地位, 不仅是 城市风格重要的展示方法, 同时还是城市面貌重要的展示方法, 而在建 筑设计中融入文化特色, 可以作为城市发展的一个标志, 保证城市建设 经济的健康发展。在设计建筑物的时候, 需要对城市的文化特色内容进 行充分的挖掘工作, 能够在城市规划设计景观中发挥着自身的价值。在 城市规划设计的过程中, 需要根据设计的整体思路来添加建筑设计中的 文化特色, 不仅可以保证城市规划设计的个性化, 还可以促进社会经济 的持续发展。

\section{3 结语}

城市规划是指导城市建设的重要纲领, 建筑是城市建设的重要物质基 础, 两者的规划设计要在相应的高度、思想基础上开展工作, 相关设计人员 不仅要关注建筑设计的个性化, 还要确保建筑设计能够符合城市规划设计 标准要求, 努力发挥出建筑设计的功用, 为城市建设增光添彩。

\section{[参考文献]}

[1]林百曼.生态建筑设计在城市规划设计中的应用研究 [J].绿色环保 建材,2019,(05):91.

[2]徐虎.浅析城市规划与建筑设计的联系与协调 [J]. 消防界 (电子 版),2018,4(24):45+47.

[3]许静.城市规划设计中生态建筑设计的应用分析[J].城市建设理论 研究(电子版),2019,(03): 19-20.

作者简介:

李伟(1978--), 男, 浙江人,汉族, 本科,身份证号码: 210604197804240018 , 助理工程师, 研究方向: 建筑技术及发展。 